\title{
Bioactive compounds and antioxidant activity during maturation of strawberry guava fruit ${ }^{1}$
}

\author{
Compostos bioativos e atividade antioxidante durante a maturação de frutos de \\ araçazeiros
}

\author{
Ana Lima Dantas ${ }^{2}$, Silvanda de Melo Silva ${ }^{3 *}$, Maria Auxiliadora Coêlho de Lima ${ }^{4}$, Renato Lima Dantas² e \\ Rejane Maria Nunes Mendonça ${ }^{3}$
}

\begin{abstract}
The objective of this work was to evaluate bioactive compounds and antioxidant activity of the fruit of strawberry-guava genotypes during maturation, and identify the characteristics that influenced the genetic variability. The fruits were harvested from 15 naturally-occurring genotypes in Areia, Paraíba, Brazil, at the following stages of maturation: Completely Green; Start of Yellow Coloration; Mainly Yellow Coloration and Completely Yellow. During maturation, the ascorbic acid content increased as the chlorophyll and yellow flavonoids were reduced. Antioxidant activity increased with advancing maturity, being greater for the P1, P4, P6, P7, P14 and P15 genotypes. Principal component analysis showed that during maturation, variability among fruits of the strawberry guava was related to the ascorbic acid and carotenoid contents.
\end{abstract}

Key words: Strawberry guava. Quality. Adding Value. Genetic Resources.

\begin{abstract}
RESUMO - O objetivo deste trabalho foi avaliar compostos bioativos e atividade antioxidante de frutos de genótipos de araçazeiros durante a maturação e identificar as características que influenciaram a variabilidade genética. Os frutos foram colhidos a partir de 15 genótipos de ocorrência espontânea no município de Areia-PB, nos seguintes estádios de maturação: Totalmente Verde, Início de Pigmentação Amarela, Pigmentação Amarela Predominante e Totalmente Amarela. Durante a maturação, o conteúdo de ácido ascórbico aumentou paralelo à redução da clorofila total e flavonoides amarelos. A atividade antioxidante aumentou com o avanço da maturação, sendo a dos genótipos P1, P4, P6, P7, P14 e P15 superior aos demais. A análise de componentes principais mostrou que, durante a maturação, a variabilidade entre frutos de genótipos de araçazeiros foi relacionada aos conteúdos de ácido ascórbico e carotenoides.
\end{abstract}

Palavras-chave: Araçá. Qualidade. Agregação de Valor. Recursos Genéticos.

\footnotetext{
* Autor para correspondência

Recebido para publicação em 07/03/2012; aprovado em 04/07/2013

Parte de Dissertação de Mestrado da primeira autora apresentado no Programa Pós-Graduação em Agronomia/PPGA/CCA/UFPB, e de Projeto financiado pelo CNPq

${ }^{2}$ Programa de Pós-Graduação em Agronomia/PPGA/CCA/UFPB, Areia-PB, Brasil, 58.397-000, dantas.ana.lima@gmail.com, renato_dantas@ hotmail.com.br

${ }^{3}$ Laboratório de Biologia e Tecnologia Pós-Colheita/PPGA/CCA/UFPB, Caixa Postal 04, Areia-PB, Brasil, 58.397-000, silvasil@cca.ufpb.br, rejaneufpb@cca.ufpb.br

${ }^{4}$ Embrapa Semiárido, Petrolina-PE, Brasil, auxiliadora.lima@embrapa.br
} 


\section{INTRODUCTION}

Non-traditional fruits are those which come from species considered as being native or exotic to a given region and which are unfamiliar to consumers but have distinct merit, due to their attractive appearance, unique flavour and aroma, added nutritional value and ready availability for marketing at harvest time. They are however still not planted commercially and there are no criteria for their harvest or post-harvest storage. In developed countries, where it is sought to add value to farms by introducing such activities as ecotourism associated with local products, the goal has been to restore these fruits commercially (AGOSTINI-COSTA et al., 2006).

The strawberry guava, which is one of the nontraditional plant species in the northeast of Brazil, grows spontaneously in many places, and according to Bezerra et al. (2006), numerous species of the genus Psidium which produce edible fruits can be found in all regions of the country. The fruits have a pleasant taste, besides containing compounds of a possible antioxidant potential that has aroused scientific interest (FETTER et al., 2010; GENOVESE et al., 2008; GIACOBBO et al., 2008), and show good prospects for their introduction as functional additives in food, providing added value to the food industry which seeks to include natural components that may bring benefits for human health (DEGASPARI; WASZCZYNSKYJ, 2004).

Genovese et al. (2008), in a study of frozen fruit pulp sold in Brazil, reported that the pulp of $P$. guineensis has bioactive compounds such as vitamin $\mathrm{C}$ and flavonoids, and maintains significant levels of these compounds during frozen storage. The fruit and frozen pulp of this species are rich in such flavonoids as quercetin, and show antioxidant activity similar to native fruits such as the сириас̧и, soursop [graviola], tamarind and bacuri (GONÇALVES; LAJOLO; GENOVESE, 2010). The strawberry guava can therefore be used in the preparation of juice and pulp without any great nutrient losses during processing and frozen storage, while having good sensory characteristics.

The fruit of the strawberry guava have a high potential for usage, yet remain almost unexploited in the Brejo Paraibano region. Possible uses range from its potential in a healthy diet to promising characteristics as a crop, making it an economical alternative for small farmers. It is therefore necessary to compile information relating to changes in the intrinsic characteristics of the fruit during maturation, which may help identify promising genetic material in situ, providing benefits for the genetic breeding of this species.
The aim of this work was to evaluate the bioactive-compound content and antioxidant activity of fruit of genotypes of the strawberry guava during maturation. Additionally, changes among fruits during the various stages of maturation were interrelated, in order to identify the characteristics that influence variability among genotypes.

\section{MATERIAL AND METHODS}

The experiment was conducted in 2010 at the Laboratório de Biologia e Tecnologia Pós-Colheita at the Centro de Ciências Agrárias da Universidade Federal da Paraíba (CCA/UFPB). Fruits of the strawberry guava (Psidium sp.) were harvested from fifteen spontaneous genotypes on the Macacos and Tapuio farms in Areia, in the state of Paraiba $\left(06^{\circ} 57^{\prime} 46^{\prime \prime} \mathrm{S}, 35^{\circ} 41^{\prime} 31^{\prime}\right.$ ' W, at an altitude of $623 \mathrm{~m}$ ), which according to the Köppen classification has a hot, humid climate (type AS), with rainfall in the autumn and winter.

Genotypes from P1 to P15 were identified, with the fruit being harvested manually and transported in cool boxes to the laboratory where they were sorted by maturation stage: Completely Green, Start of Yellow Coloration, Mainly Yellow Coloration and Completely Yellow Coloration. For evaluation of the fruit, the seeds were removed and the pulp macerated until homogeneous. This was then stored at $-85^{\circ} \mathrm{C}$.

The ascorbic acid content was determined by titration using a DPI solution (2.6-dichloro-phenolindophenol $0.002 \%$ ) (ASSOCIATION OFFICIAL ANALYTICAL CHEMISTS INTERNATIONAL, 2006). The total chlorophyll content and total carotenoids and yellow flavonoids in the skin were determined by spectrophotometry at 652,450 and $374 \mathrm{~nm}$ respectively (BRUUINSMA 1963), (BRITO PRIMO, 2005), (FRANCIS 1982).

The antioxidant activity was measured by phenolic extraction, using $0.5 \mathrm{~g}$ of pulp in $4 \mathrm{~mL}$ of a methanol/water solution $(50: 50, \mathrm{v} / \mathrm{v})$. The mixture was incubated for 1 hour and centrifuged for 15 minutes (15,000 rpm). The supernatant was removed and transferred to a graduated test tube. Four $\mathrm{mL}$ of an acetone/water solution $(70: 30, \mathrm{v} / \mathrm{v})$ was added to the residue, which was then incubated for 1 hour, followed by 15 minutes of centrifugation. The supernatant was removed and added to the first batch, and the volume made up to $10 \mathrm{~mL}$ with distilled water. The antioxidant activity (g pulp g DPPH ${ }^{-1}$ ) was determined by capture of the free radical DPPH (1.1-diphenil-2-picrylhydrazyl). Three dilutions of the phenolic extract were prepared (200; 400 and $600 \mu \mathrm{L} \mathrm{mL}^{-1}$ ), seeking decreasing linearity 
in absorbency, based on the standard curve for DPPH. These were incubated at room temperature, at dark for 30 minutes. However, for the Completely Yellow maturation stage, dilutions of 150,300 and $450 \mu \mathrm{L} \mathrm{mL}^{-1}$ were used, as these presented a better fit to the standard DPPH curve. An aliquot portion of $100 \mu \mathrm{L}$ for $3.9 \mathrm{~mL}$ DPPH radical $(0.06 \mathrm{mM})$ was taken from each dilution. As control, $100 \mu \mathrm{L}$ of a solution of $50 \%$ methyl alcohol $+70 \%$ acetone was used (RUFINO et al., 2010).

The experimental design was completely randomized, with fruit from fifteen strawberry guava genotypes being evaluated at four maturation stages, using three replications for the evaluations consisting of 20 fruits replic ${ }^{-1}$. Data were subjected to variance analysis (ANOVA) at 5\%. Averages for the maturation stages for each genotype were compared by Tukey test. The averages of the genotypes for each maturation stage were compared by the Scott-Knott test. Principal component analysis (PCA) was carried out for different sets of variables for each maturation stage using the Statistica 7.0 software (2004). The eigenvector circle of the variables was constructed for each PCA, considering a correlation coefficient of from $|\mathrm{r}|=0.70$, representing those components indicating a cumulative variance of from $60 \%$. The ordination diagram of genotypes was constructed based on the correlation matrix of the principal components 1 and 2 .

\section{RESULTS AND DISCUSSION}

The strawberry guava genotypes which were evaluated showed an increase in the levels of ascorbic acid with advancing maturity (Table 1), but fruits of the P8, P9, P10, and P11 genotypes showed a lower content than the others, and were thus responsible for the low average content of this bioactive compound. For fruits at the Completely Yellow (CY) stage of maturation, the remaining genotypes showed contents ranging from 39.27 to $94.84 \mathrm{mg} 100 \mathrm{~g}^{-1}$. Increases in the ascorbic acid content

Table 1 - Ascorbic acid content (mg $100 \mathrm{~g}^{-1}$ ) of strawberry guava pulp (Psidium sp.) for the maturation stages: Completely Green (CG), Start of Yellow Coloration (SY), Mainly Yellow Coloration (MY), and Completely Yellow Coloration (CY)

\begin{tabular}{|c|c|c|c|c|c|}
\hline \multirow{2}{*}{ Genotype } & \multicolumn{5}{|c|}{ Maturation stage } \\
\hline & $\mathrm{CG}$ & SY & MY & $\mathrm{CY}$ & C.V. $(\%)$ \\
\hline $\mathrm{P} 1$ & $13.12 \mathrm{Ed}$ & $17.22 \mathrm{Fc}$ & $66.66 \mathrm{Aa}$ & $61.24 \mathrm{Db}$ & 3.39 \\
\hline $\mathrm{P} 2$ & 17.11 Dd & $27.04 \mathrm{Ec}$ & $37.87 \mathrm{~Gb}$ & $40.37 \mathrm{Ha}$ & 1.57 \\
\hline P3 & $13.31 \mathrm{Ec}$ & $15.02 \mathrm{Gc}$ & $40.21 \mathrm{~Gb}$ & $70.03 \mathrm{Ca}$ & 8.24 \\
\hline P4 & $10.60 \mathrm{Ed}$ & $18.72 \mathrm{Fc}$ & $30.37 \mathrm{Ib}$ & $39.27 \mathrm{Ha}$ & 2.50 \\
\hline P5 & $11.69 \mathrm{Ec}$ & $17.40 \mathrm{Fb}$ & $51.06 \mathrm{Ca}$ & $53.04 \mathrm{Ea}$ & 6.59 \\
\hline P6 & $12.36 \mathrm{Ec}$ & $17.96 \mathrm{Fc}$ & $48.36 \mathrm{Db}$ & $94.84 \mathrm{Aa}$ & 6.28 \\
\hline P7 & $11.00 \mathrm{Ec}$ & $13.35 \mathrm{Gc}$ & $55.33 \mathrm{Bb}$ & $74.56 \mathrm{Ba}$ & 9.09 \\
\hline P8 & $9.65 \mathrm{Ec}$ & $12.05 \mathrm{Hb}$ & $13.68 \mathrm{Mb}$ & $16.62 \mathrm{Ja}$ & 5.23 \\
\hline P9 & $10.00 \mathrm{Ec}$ & $10.69 \mathrm{Hbc}$ & 12.87 Mab & $14.38 \mathrm{Ja}$ & 8.92 \\
\hline P10 & $12.50 \mathrm{Ec}$ & $20.06 \mathrm{Fb}$ & $21.96 \mathrm{Lb}$ & $26.65 \mathrm{Ia}$ & 6.66 \\
\hline P11 & $11.76 \mathrm{Ec}$ & $24.84 \mathrm{Ea}$ & $26.39 \mathrm{Ja}$ & $14.29 \mathrm{Jb}$ & 4.21 \\
\hline $\mathrm{P} 12$ & $30.96 \mathrm{Bd}$ & $36.75 \mathrm{Cc}$ & $46.14 \mathrm{~Eb}$ & $52.11 \mathrm{Ea}$ & 4.55 \\
\hline P13 & $30.86 \mathrm{Bb}$ & $34.60 \mathrm{Bb}$ & $48.66 \mathrm{Da}$ & $49.33 \mathrm{Fa}$ & 6.40 \\
\hline P14 & $36.27 \mathrm{Ac}$ & $40.25 \mathrm{Abc}$ & $42.53 \mathrm{Cab}$ & $45.69 \mathrm{Ga}$ & 3.39 \\
\hline $\mathrm{P} 15$ & $25.26 \mathrm{Cc}$ & $29.54 \mathrm{Dc}$ & $37.43 \mathrm{~Gb}$ & $44.42 \mathrm{Ga}$ & 5.28 \\
\hline Mean & $17.10 \mathrm{~d}$ & $22.37 \mathrm{c}$ & $38.64 \mathrm{~b}$ & $46.45 \mathrm{a}$ & - \\
\hline Maximum & 37.44 & 37.44 & 67.45 & 67.45 & - \\
\hline Minimum & 8.65 & 8.65 & 11.88 & 11.88 & - \\
\hline C.V. $(\%)$ & 6.00 & 6.36 & 5.10 & 5.95 & - \\
\hline
\end{tabular}

Means followed by the same letter do not differ among themselves, for lower-case on a line by the Tukey test (maturation stages) and for uppercase in a column by the Scott-Knott test (genotypes) at $5 \%$ 
with advancing maturity, were also reported in guava (AZZOLINI; JACOMINO; BRON, 2004; SOUZA et al., 2010) and star fruit [carambola] (PATIL et al., 2010). However, in the P1 and P11 genotypes, levels decreased in the final stage of maturation, which may have been due to the characteristics of the fruit from these plants, as in the melon (BREZEANU; BREZEANU; AMBANUS, 2010) and West Indian cherry (acerola) ) (BADEJO; FUJIKAWA; ESAKA, 2009).

Fruits of the P14 genotype showed the highest levels of ascorbic acid for the stages Completely Green (CG) and Start of Yellow Coloration (SY), with values of 36.27 and $40.25 \mathrm{mg} 100 \mathrm{~g}^{-1}$ respectively. For guava with Mainly Yellow Coloration (MY), the highest levels of ascorbic acid were obtained from the P1 genotype, with $66.66 \mathrm{mg} 100 \mathrm{~g}^{-1}$, and for those of Completely

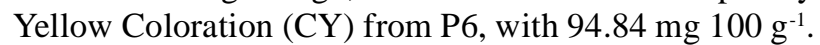
Giacobbo et al. (2008) reported vitamin $\mathrm{C}$ in guava from Pelotas, Rio Grande do Sul, with levels of less than $30 \mathrm{mg}$ $100 \mathrm{~g}^{-1}$ for the yellow fruit and around $44 \mathrm{mg} 100 \mathrm{~g}^{-1}$ for the red, for the maturation stage with that characteristic coloration, having levels close to those for ascorbic acid obtained in this work.

Genovese et al. (2008), evaluating the content of ascorbic acid in some species of the Myrtaceae family, in the State of São Paulo, reported 9.5, 397.0 and $4.8 \mathrm{mg} 100 \mathrm{~g}^{-1}$ for araçá-boi, camu-camu and strawberry guava ( $P$. guineensis) respectively. Andrade, Aragão and Ferreira (1993) reported for the guava $389.34 \mathrm{mg} 100 \mathrm{~g}^{-1}$, and Brito Primo (2005), for the strawberry guava of the Brejo Paraibano region, a variation of from 145.85 to $266.39 \mathrm{mg} 100 \mathrm{~g}^{-1}$ during maturation, being much higher than the ascorbic acid content reported in this work.

Decreases were observed in the total chlorophyll levels of the guava as maturation advanced, and values of between 21.22 and $1.17 \mathrm{mg} 100 \mathrm{~g} \mathrm{~g}^{-1}$ were found in the Completely Green (P13) and Completely Yellow (P3) stages respectively (Table 2 ). With the advance in fruit maturation, one of the major changes is that of outside coloration, when the chlorophyll in the chloroplasts is

Table 2 - Skin chlorophyll content (100 $\mathrm{mg} \mathrm{g}^{-1}$ ) of strawberry guava fruit (Psidium sp.) for the maturation stages: Completely Green (CG), Start of Yellow Coloration (SY), Mainly Yellow Coloration (MY) and Completely Yellow Coloration (CY)

\begin{tabular}{|c|c|c|c|c|c|}
\hline \multirow{2}{*}{ Genotype } & \multicolumn{5}{|c|}{ Maturation stage } \\
\hline & $\mathrm{CG}$ & SY & MY & $\mathrm{CY}$ & C.V. $(\%)$ \\
\hline $\mathrm{P} 1$ & $9.60 \mathrm{Da}$ & $5.28 \mathrm{Db}$ & $3.84 \mathrm{Cbc}$ & $2.46 \mathrm{Bc}$ & 16.29 \\
\hline $\mathrm{P} 2$ & $13.56 \mathrm{Ba}$ & $8.35 \mathrm{Bb}$ & $5.11 \mathrm{Bc}$ & $2.52 \mathrm{Bd}$ & 12.50 \\
\hline P3 & $7.05 \mathrm{Ea}$ & $5.01 \mathrm{Da}$ & $2.46 \mathrm{Cb}$ & $1.17 \mathrm{Bb}$ & 24.56 \\
\hline P4 & $5.48 \mathrm{Ea}$ & 4.79 Da & $2.02 \mathrm{Cb}$ & $1.74 \mathrm{Bb}$ & 15.52 \\
\hline P5 & $11.37 \mathrm{Ca}$ & $5.25 \mathrm{Db}$ & $3.60 \mathrm{Cb}$ & $3.55 \mathrm{Bb}$ & 18.76 \\
\hline P6 & $12.31 \mathrm{Ca}$ & $7.01 \mathrm{Cb}$ & $3.06 \mathrm{Cbc}$ & $1.92 \mathrm{Bc}$ & 26.87 \\
\hline P7 & $20.19 \mathrm{Aa}$ & $9.55 \mathrm{Bb}$ & $3.55 \mathrm{Cc}$ & $1.95 \mathrm{Bc}$ & 12.43 \\
\hline P8 & $20.88 \mathrm{Aa}$ & $9.21 \mathrm{Bb}$ & $3.57 \mathrm{Cc}$ & $2.86 \mathrm{Bc}$ & 5.96 \\
\hline P9 & $13.66 \mathrm{Ba}$ & $7.55 \mathrm{Cb}$ & $3.83 \mathrm{Cc}$ & $2.66 \mathrm{Bc}$ & 9.05 \\
\hline $\mathrm{P} 10$ & $13.36 \mathrm{Ba}$ & $6.96 \mathrm{Cb}$ & $3.52 \mathrm{Cc}$ & $2.71 \mathrm{Bc}$ & 14.43 \\
\hline P11 & $9.03 \mathrm{Da}$ & $5.75 \mathrm{Db}$ & $2.97 \mathrm{Cc}$ & $2.34 \mathrm{Bc}$ & 17.34 \\
\hline $\mathrm{P} 12$ & $12.92 \mathrm{Ba}$ & $11.48 \mathrm{Aa}$ & $7.88 \mathrm{Ab}$ & $5.17 \mathrm{Ab}$ & 11.39 \\
\hline P13 & $21.22 \mathrm{Aa}$ & $11.86 \mathrm{Ab}$ & $6.09 \mathrm{Bc}$ & $4.91 \mathrm{Ac}$ & 8.79 \\
\hline $\mathrm{P} 14$ & $19.69 \mathrm{Aa}$ & $8.34 \mathrm{Bb}$ & $6.89 \mathrm{Ab}$ & $4.93 \mathrm{Ab}$ & 16.65 \\
\hline $\mathrm{P} 15$ & $14.71 \mathrm{Ba}$ & $10.15 \mathrm{Bb}$ & $5.33 \mathrm{Bc}$ & $2.69 \mathrm{Bc}$ & 13.17 \\
\hline Mean & $13.67 \mathrm{a}$ & $7.77 \mathrm{~b}$ & $4.25 \mathrm{c}$ & $2.90 \mathrm{~d}$ & - \\
\hline Maximum & 22.63 & 13.19 & 9.89 & 5.85 & - \\
\hline Minimum & 4.63 & 4.35 & 1.91 & 0.78 & - \\
\hline C.V. $(\%)$ & 11.77 & 10.38 & 17.59 & 25.41 & - \\
\hline
\end{tabular}

Means followed by the same letter do not differ among themselves, for lower-case on a line by the Tukey test (maturation stages) and for uppercase in a column by the Scott-Knott test (genotypes) at 5\% 
broken down by the enzyme chlorophyllase, resulting in the loss of green coloration and the development of characteristic coloration, giving rise to chromoplasts (CHITARRA; CHITARRA, 2005), so that other pigments which are responsible for the characteristic colour of the ripe fruits are seen (PALIYATH; MURR, 2008).

A decrease was also observed in the total carotenoid content during ripening of the strawberry guava fruit, however among the evaluated genotypes some values did not differ between maturation stages (Table 3) despite a change in skin colour being evident. In the strawberry guava therefore, breakdown of chlorophyll is the determining factor in the change of skin colour, indicating that carotenoids are already present in the fruits at the beginning of maturation, and are only seen with breakdown of the chlorophyll (CHITARRA; CHITARRA, 2005).

The carotenoid content ranged from 0.193 to $0.133 \mathrm{mg} 100 \mathrm{~g}^{-1}$ for the Completely Green to Completely Yellow maturation stages. Higher values were obtained for the P14 genotype, at the Completely Yellow and Start of Yellow maturation stages, with 0.395 and $0.339 \mathrm{mg} 100 \mathrm{~g}^{-1}$ respectively. For the Mainly Yellow stage, the highest content was in the P8 genotype with $0.308 \mathrm{mg} 100 \mathrm{~g}^{-1}$. For the Completely Yellow stage, the carotenoid content was higher in fruits of the P1 genotype, with $0.258 \mathrm{mg} 100 \mathrm{~g}^{-1}$. These values are lower than those reported for the yellow guava (1.07 mg $\left.100 \mathrm{~g}^{-1}\right)$, red guava $\left(0.990 \mathrm{mg} 100 \mathrm{~g}^{-1}\right)$, and for guava $\left(0.590 \mathrm{mg} 100 \mathrm{~g}^{-1}\right)$ grown in Pelotas, Rio Grande do Sul (FETTER et al., 2010). Carotenoids, besides giving the fruit a characteristic color, are bioactive compounds of importance in human nutrition for their antioxidant properties, acting in the capture of free radicals (PALIYATH; MURR, 2008).

The levels of yellow flavonoids decreased with advancing maturity, ranging from 21.56 for the

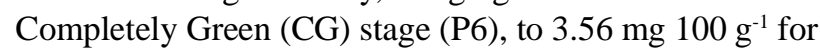
the Completely Yellow (CY) stage (P15) (Table 4). The P6 genotype had the highest yellow flavonoid content for Completely Green fruit, but for P11, it was higher at the

Table 3 - Total carotenoid content of the skin (mg $100 \mathrm{~g}^{-1}$ ) of strawberry guava fruit (Psidium sp.) for the maturation stages: Completely Green (CG), Start of Yellow Coloration (SY), Mainly Yellow Coloration (MY) and Completely Yellow Coloration (CY)

\begin{tabular}{|c|c|c|c|c|c|}
\hline \multirow{2}{*}{ Genotype } & \multicolumn{5}{|c|}{ Maturation stage } \\
\hline & $\mathrm{CG}$ & SY & MY & $\mathrm{CY}$ & C.V. (\%) \\
\hline $\mathrm{P} 1$ & $0.223 \mathrm{Ca}$ & $0.225 \mathrm{Ba}$ & $0.259 \mathrm{Ba}$ & $0.258 \mathrm{Aa}$ & 9.41 \\
\hline $\mathrm{P} 2$ & $0.200 \mathrm{Ca}$ & $0.191 \mathrm{Ca}$ & $0.164 \mathrm{Ca}$ & $0.158 \mathrm{Ba}$ & 13.70 \\
\hline P3 & $0.145 \mathrm{Db}$ & $0.173 \mathrm{Cab}$ & $0.191 \mathrm{Ca}$ & $0.090 \mathrm{Dc}$ & 10.65 \\
\hline P4 & $0.163 \mathrm{Da}$ & $0.141 \mathrm{Da}$ & $0.150 \mathrm{Ca}$ & $0.162 \mathrm{Ba}$ & 21.78 \\
\hline P5 & $0.318 \mathrm{Ba}$ & $0.132 \mathrm{Db}$ & $0.122 \mathrm{Cb}$ & $0.091 \mathrm{Db}$ & 12.57 \\
\hline P6 & $0.106 \mathrm{Da}$ & $0.078 \mathrm{Ea}$ & $0.077 \mathrm{Da}$ & $0.067 \mathrm{Da}$ & 18.76 \\
\hline P7 & $0.168 \mathrm{Da}$ & $0.187 \mathrm{Ca}$ & $0.143 \mathrm{Ca}$ & $0.120 \mathrm{Ca}$ & 20.89 \\
\hline P8 & $0.170 \mathrm{Dc}$ & $0.248 \mathrm{Bb}$ & $0.308 \mathrm{Aa}$ & $0.082 \mathrm{Dd}$ & 4.69 \\
\hline P9 & $0.145 \mathrm{Db}$ & $0.280 \mathrm{Ba}$ & $0.155 \mathrm{Cb}$ & $0.125 \mathrm{Cb}$ & 10.75 \\
\hline P10 & $0.154 \mathrm{Da}$ & $0.172 \mathrm{Ca}$ & $0.181 \mathrm{Ca}$ & $0.145 \mathrm{Ba}$ & 16.30 \\
\hline P11 & $0.139 \mathrm{Da}$ & $0.107 \mathrm{Eab}$ & $0.067 \mathrm{Db}$ & $0.081 \mathrm{Db}$ & 22.17 \\
\hline P12 & $0.143 \mathrm{Da}$ & $0.178 \mathrm{Ca}$ & $0.179 \mathrm{Ca}$ & $0.160 \mathrm{Ba}$ & 11.26 \\
\hline $\mathrm{P} 13$ & $0.189 \mathrm{Cb}$ & $0.264 \mathrm{Ba}$ & $0.161 \mathrm{Cb}$ & $0.139 \mathrm{Bb}$ & 11.19 \\
\hline P14 & $0.395 \mathrm{Aa}$ & $0.339 \mathrm{Aa}$ & $0.222 \mathrm{Bb}$ & $0.156 \mathrm{Bb}$ & 10.77 \\
\hline $\mathrm{P} 15$ & $0.231 \mathrm{Ca}$ & $0.201 \mathrm{Cab}$ & $0.170 \mathrm{Cab}$ & $0.155 \mathrm{Bb}$ & 14.62 \\
\hline Mean & $0.193 \mathrm{a}$ & $0.194 \mathrm{a}$ & $0.170 \mathrm{~b}$ & $0.133 \mathrm{c}$ & - \\
\hline Maximum & 0.43 & 0.36 & 0.31 & 0.29 & - \\
\hline Minimum & 0.10 & 0.07 & 0.05 & 0.05 & - \\
\hline C.V. $(\%)$ & 11.96 & 10.72 & 18.43 & 13.39 & - \\
\hline
\end{tabular}

Means followed by the same letter do not differ among themselves, for lower-case on a line by the Tukey test (maturation stages) and for uppercase in a column by the Scott-Knott test (genotypes) at $5 \%$ 
Table 4 - Yellow flavonoid content (mg $100 \mathrm{~g}^{-1}$ ) of strawberry guava pulp (Psidium sp.) for the maturation stages: Completely Green (CG), Start of Yellow Coloration (SY), Mainly Yellow Coloration (MY), and Completely Yellow Coloration (CY)

\begin{tabular}{lccccc}
\hline \multirow{2}{*}{ Genotype } & \multicolumn{5}{c}{ Maturation stage } \\
\cline { 2 - 6 } & $\mathrm{CG}$ & $\mathrm{SY}$ & $\mathrm{MY}$ & $\mathrm{CY}$ & C.V. (\%) \\
\hline P1 & $10.88 \mathrm{Ca}$ & $5.89 \mathrm{~Eb}$ & $4.56 \mathrm{Cbc}$ & $3.59 \mathrm{Cc}$ & 9.43 \\
P2 & $6.99 \mathrm{Fa}$ & $4.48 \mathrm{Fb}$ & $4.80 \mathrm{Cb}$ & $4.43 \mathrm{Cb}$ & 10.46 \\
P3 & $13.07 \mathrm{Ba}$ & $9.26 \mathrm{Cb}$ & $9.45 \mathrm{Ab}$ & $9.59 \mathrm{Ab}$ & 3.30 \\
P4 & $6.56 \mathrm{Fa}$ & $7.27 \mathrm{Da}$ & $7.21 \mathrm{Ba}$ & $5.85 \mathrm{Ba}$ & 10.85 \\
P5 & $9.30 \mathrm{Da}$ & $5.84 \mathrm{~Eb}$ & $4.61 \mathrm{Cb}$ & $3.61 \mathrm{Cb}$ & 10.06 \\
P6 & $21.56 \mathrm{Aa}$ & $7.52 \mathrm{Db}$ & $6.43 \mathrm{Bbc}$ & $5.54 \mathrm{Bb}$ & 8.43 \\
P7 & $9.50 \mathrm{Da}$ & $7.91 \mathrm{Dab}$ & $6.92 \mathrm{Bbc}$ & $5.85 \mathrm{Bc}$ & 10.17 \\
P8 & $11.39 \mathrm{Ca}$ & $6.82 \mathrm{~Eb}$ & $6.37 \mathrm{Bb}$ & $6.26 \mathrm{Bb}$ & 9.00 \\
P9 & $8.78 \mathrm{Ea}$ & $5.13 \mathrm{Fb}$ & $5.28 \mathrm{Cb}$ & $3.86 \mathrm{Cb}$ & 19.67 \\
P10 & $11.28 \mathrm{Ca}$ & $8.16 \mathrm{Db}$ & $8.67 \mathrm{Ab}$ & $4.87 \mathrm{Bc}$ & 9.27 \\
P11 & $13.66 \mathrm{Ba}$ & $12.79 \mathrm{Aa}$ & $7.23 \mathrm{Bb}$ & $5.21 \mathrm{Bc}$ & 4.06 \\
P12 & $8.62 \mathrm{Ea}$ & $8.10 \mathrm{Da}$ & $5.62 \mathrm{Cb}$ & $5.36 \mathrm{Bb}$ & 10.62 \\
P13 & $6.15 \mathrm{Fb}$ & $10.32 \mathrm{Ba}$ & $7.26 \mathrm{Bb}$ & $5.52 \mathrm{Bb}$ & 14.96 \\
P14 & $6.04 \mathrm{Fa}$ & $4.13 \mathrm{Fb}$ & $3.99 \mathrm{Db}$ & $3.72 \mathrm{Cb}$ & 14.79 \\
P15 & $4.82 \mathrm{Ga}$ & $4.60 \mathrm{Fa}$ & $3.63 \mathrm{Db}$ & $3.56 \mathrm{Cb}$ & 5.93 \\
\hline Mean & $9.91 \mathrm{a}$ & $7.22 \mathrm{~b}$ & $6.13 \mathrm{c}$ & $5.12 \mathrm{~d}$ & - \\
\hline Maximum & 23.40 & 13.05 & 9.73 & 9.77 & - \\
Minimum & 4.75 & 3.92 & 3.05 & 2.93 & - \\
C.V. $(\%)$ & 9.01 & 7.98 & 13.80 & 11,60 & - \\
\hline
\end{tabular}

Means followed by the same letter do not differ among themselves, for lower-case on a line by the Tukey test (maturation stages) and for uppercase in a column by the Scott-Knott test (genotypes) at $5 \%$

Start of Yellow Colouration. The P3 genotype showed higher flavonoids in fruits with Mainly Yellow Coloration. The guava showed an average flavonoid content less

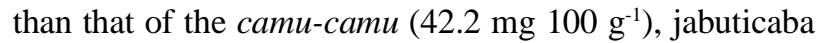
(147.0 mg $100 \mathrm{~g} \mathrm{~g}^{-1}$ ), jambul (70.9 mg $100 \mathrm{~g}^{-1}$ ) and myrtle (207.0 mg $100 \mathrm{~g}^{-1}$ ) (RUFINO et al., 2010). Arora, Nair and Strasburg (1998) and Silva et al. (2002) when studying the antioxidant activity of the fruit, checked the efficacy of flavonoid groups, including those with yellow pigmentation in their composition.

The antioxidant activity of the guava increased with advancing maturity, demonstrated by a decrease in $\mathrm{EC}_{50}$ (the amount of guava pulp in $\mathrm{g}$ required to reduce $50 \%$ of the initial concentration of DPPH - g pulp g DPPH ${ }^{-1}$ ) (Table 5).

Antioxidant activity of the guava increases with advancing maturity, where values in the ripe fruit were higher than those in other fruits of recognized antioxidant potential (camu-camu, jabuticaba, and uvaia). Antioxidant activity (AA) was different between the strawberry guava genotypes for each maturation stage. The lowest AA for the Completely Green stage was seen in the P14 genotype $\left(1,322.46 \mathrm{~g}\right.$ pulp $\left.\mathrm{g} \mathrm{DPPH}^{-1}\right)$. For the remaining stages lower values were observed in the fruit of genotype P9. In contrast, those genotypes that showed the greatest AA for the four stages evaluated were P4, P6 and P7 and were indicated as being the most promising. The different values observed for antioxidant activity are due to the intrinsic characteristics of the fruit, to the method used for obtaining the extract, the extraction solution, the method of determination, and the compounds with an antioxidant action present in the tested material (MUSA et al., 2011).

Genovese et al. (2008) reported a capacity of

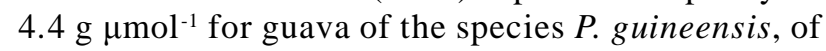
$1.8 \mathrm{~g} \mathrm{\mu mol}^{-1}$ in the araçá boi (Eugenia stipitata), of $141.0 \mathrm{~g} \mathrm{\mu mol}^{-1}$ in camu-camu and of $9.0 \mathrm{~g} \mathrm{\mu mol}^{-1}$ in cambuci. Antioxidant activity was reported in frozen guava pulp of 5.9 and $7.4 \mu \mathrm{mol}$ trolox $\mathrm{g}^{-1}$ pulp, for reaction times of 30 and 60 minutes, respectively (KUSKOSKI et al., 2006). In guava from Colombia, 
Table 5 - Antioxidant activity (g pulp g DPPH ${ }^{-1}$ ) in the strawberry guava (Psidium sp for the maturation stages: Completely Green (CG), Start of Yellow Coloration (SY), Mainly Yellow Coloration (MY), and Completely Yellow Coloration (CY)

\begin{tabular}{|c|c|c|c|c|c|}
\hline \multirow{2}{*}{ Genotype } & \multicolumn{5}{|c|}{ Maturation stage } \\
\hline & $\mathrm{CG}$ & SY & MY & CY & C.V. $(\%)$ \\
\hline $\mathrm{P} 1$ & $636.44 \mathrm{Ba}$ & $304.50 \mathrm{Cb}$ & $203.22 \mathrm{Cb}$ & $131.08 \mathrm{~Eb}$ & 35.35 \\
\hline $\mathrm{P} 2$ & $323.21 \mathrm{Ca}$ & $338.81 \mathrm{Ca}$ & $301.32 \mathrm{Ca}$ & $283.29 \mathrm{Da}$ & 11.82 \\
\hline P3 & $602.87 \mathrm{Ba}$ & $414.80 \mathrm{Bb}$ & $355.84 \mathrm{Cb}$ & $277.42 \mathrm{Dc}$ & 7.25 \\
\hline P4 & $224.19 \mathrm{Ca}$ & $184.41 \mathrm{Db}$ & $161.16 \mathrm{bCc}$ & $128.54 \mathrm{Ec}$ & 7.95 \\
\hline P5 & $383.41 \mathrm{Ca}$ & $303.84 \mathrm{Cb}$ & $313.48 \mathrm{Cb}$ & $312.18 \mathrm{Db}$ & 6.59 \\
\hline P6 & $268.52 \mathrm{Ca}$ & 227.51 Dab & $260.56 \mathrm{Cb}$ & $91.97 \mathrm{Ec}$ & 6.32 \\
\hline P7 & $345.38 \mathrm{Ca}$ & $267.11 \mathrm{Cb}$ & $314.65 \mathrm{Cc}$ & $153.43 \mathrm{Ed}$ & 1.79 \\
\hline P8 & $502.72 \mathrm{Ba}$ & $446.13 \mathrm{Ba}$ & $402.00 \mathrm{Ba}$ & $372.58 \mathrm{Ca}$ & 17.20 \\
\hline P9 & $664.57 \mathrm{Ba}$ & $675.12 \mathrm{Aa}$ & $639.22 \mathrm{Aa}$ & $564.34 \mathrm{Aa}$ & 16.69 \\
\hline P10 & $704.52 \mathrm{Ba}$ & 606.76 Aab & $422.50 \mathrm{Bbc}$ & $377.87 \mathrm{Cc}$ & 14.10 \\
\hline P11 & $563.98 \mathrm{Ba}$ & 407.94 Bab & 389.07 Bab & $306.50 \mathrm{Dc}$ & 22.42 \\
\hline $\mathrm{P} 12$ & $750.90 \mathrm{Ba}$ & 405.39 Bb & $390.65 \mathrm{Bb}$ & $384.23 \mathrm{Cb}$ & 18.02 \\
\hline $\mathrm{P} 13$ & $607.01 \mathrm{Ba}$ & $450.56 \mathrm{Ba}$ & $481.59 \mathrm{Ba}$ & $469.18 \mathrm{Ba}$ & 29.43 \\
\hline P14 & $1322.43 \mathrm{Aa}$ & $512.07 \mathrm{Bb}$ & $320.52 \mathrm{Cb}$ & $328.42 \mathrm{Db}$ & 25.36 \\
\hline P15 & $476.46 \mathrm{Ba}$ & $482.52 \mathrm{Ba}$ & $305.70 \mathrm{Cb}$ & $268.87 \mathrm{Db}$ & 5.56 \\
\hline Mean & $558.44 \mathrm{a}$ & $401.83 \mathrm{~b}$ & $350.76 \mathrm{c}$ & $296.66 \mathrm{~d}$ & - \\
\hline Maximum & 1645.80 & 825.95 & 771.02 & 678.30 & - \\
\hline Minimum & 209.57 & 178.69 & 144.10 & 89.86 & - \\
\hline C.V. $(\%)$ & 22.02 & 14.47 & 21.79 & 13.38 & - \\
\hline
\end{tabular}

Means followed by the same letter do not differ among themselves, for lower-case on a line by the Tukey test (maturation stages) and for uppercase in a column by the Scott-Knott test (genotypes) at $5 \%$

a range of from 10.8 to $32.5 \mu \mathrm{mol}$ trolox $\mathrm{g}^{-1}$ was seen (ROJAS-BARQUERA; NARVÁEZ-CUENCA, 2009). Fetter et al. (2010) reported antioxidant activity measured in trolox of $7884.33 \mu \mathrm{g} \mathrm{g}^{-1}$ for

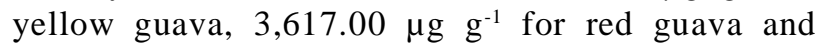
$20,324.82 \mu \mathrm{g} \mathrm{g}{ }^{-1}$ for guava. Rufino et al. (2010) reported antioxidant activity for the ripe fruit from species of the Myrtaceae family, citing the camuсатu, jabuticaba, jambul, myrtle and uvaia, with values of $478 ; 1,472 ; 3,025 ; 936$ and $3,247 \mathrm{~g}$ pulp g $\mathrm{DPPH}^{-1}$ respectively, the antioxidant activities of these fruits being inferior to that of the strawberry guava evaluated in this work.

Cluster events which came about as a function of the bioactive compounds and antioxidant activity during fruit maturation in different strawberry guava genotypes, were correlated using principal component analysis (PCA). In this way, the four maturation stages were analysed separately in order to identify the main features which account for variability between genotypes (Figure 1).
In order to explain satisfactorily the variability among genotypes at the Completely Green stage (Figure 1-CG), the first two principal components showed a cumulative variance of $70.19 \%$, with a total variance for CP1 of $54.18 \%$ and for CP2 of $16,01 \%$. CP1 was made up of the contents, in order of importance, of ascorbic acid, carotenoids, antioxidant activity and flavonoids. Genotypes located to the right of the graph showed a higher ascorbic acid and carotenoid content and lower antioxidant activity compared to the genotypes on the left. CP2, in turn, is only associated with chlorophyll content. As a function of the correlation matrix of $\mathrm{CP} 1$ and $\mathrm{CP} 2$, it was possible to form six groups for the CG stage. P14 was isolated from the remaining genotypes by the greater carotenoid and ascorbic acid content and lower antioxidant activity, being the characteristic with the greatest discrepancy observed between this and the other genotypes. Fruits of the P12, $\mathrm{P} 13$, and P15 genotypes presented similar ascorbic acid content, inferior only to that of the P14 genotype. The P7, P8, P9, and P10 genotypes were grouped because of having less ascorbic acid than the others, with the exception of 
Figure 1 - Principal component analysis for 15 strawberry guava genotypes (Psidium sp.) and the eigenvector circle of the variables: ascorbic acid (Ac.Asc.), Carotenoids (Carot.), chlorophyll (Clor.), yellow flavonoids (Flav.P .), antioxidant activity (AA), where CG = Completely Green, SY = Start of Yellow Coloration, MY = Mainly Yellow Coloration and CY = Completely Yellow Coloration
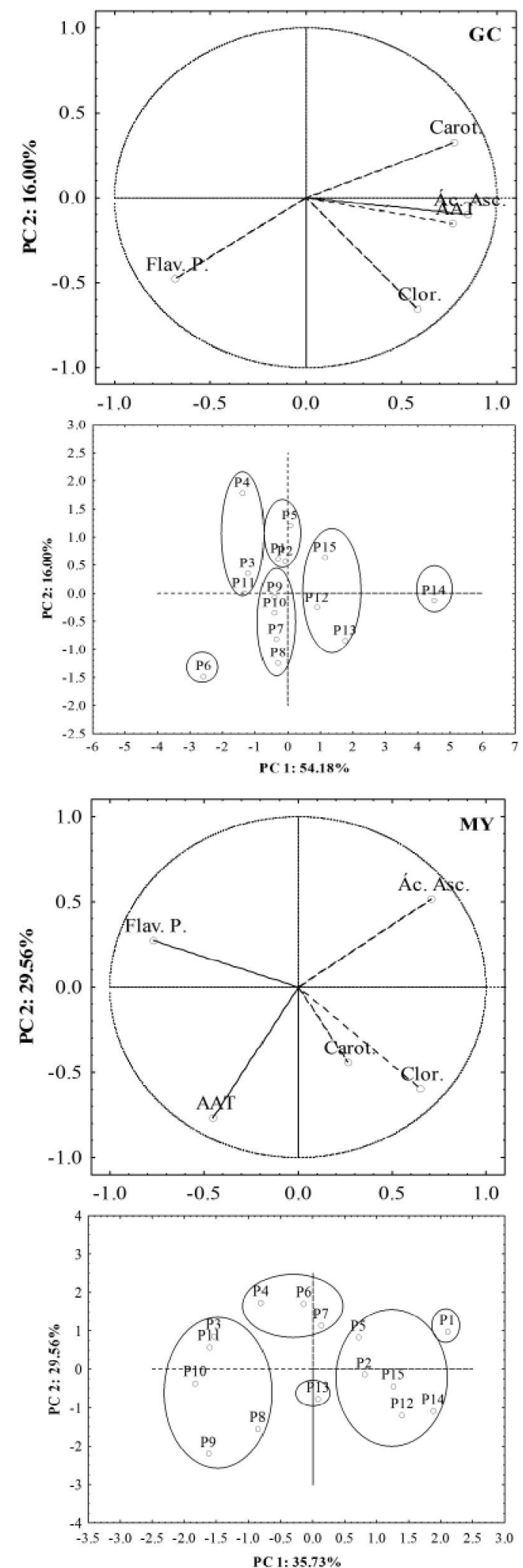
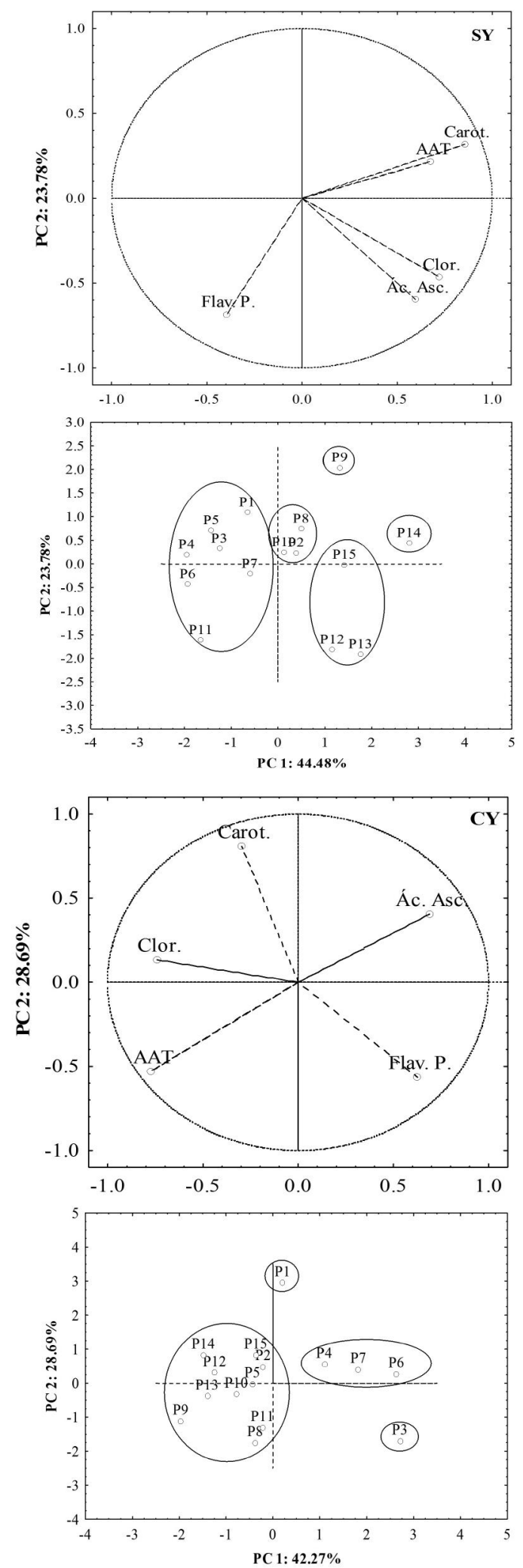
P10, which grouped due to its carotenoids. The P1, P2 and P5 genotypes showed similar carotenoid content, but the total chlorophyll and carotenoids in the fruits of P3, P4 and P11 were inferior to those of the rest.

For those fruits at the Start of Yellow Coloration, it was possible to form five groups whose variation was explained to $68.26 \%$ by CP1 $(44.48 \%)$ and CP2 $(23.78 \%)$ (Figure 1-SY). CP1 was represented by carotenoid and chlorophyll content and antioxidant activity, and CP2 by flavonoid content. The P14 genotype was therefore isolated due to the carotenoid content being greater than in the remainder, and its ascorbic acid being prominent. The P12, P13 and P15 genotypes, which had a higher ascorbic acid content, were separated from P14 due to the carotenoid discrepancy. The P9 genotype had less ascorbic acid than the rest, while the antioxidant activity of P2, P8 and P10 was greater. The P1, P3, P4, P5, P6 and $\mathrm{P} 11$ genotypes presented a carotenoid content which was lower, with the exception of $\mathrm{P} 1$, which was included in the group because of its ascorbic acid content.

For fruits with Mainly Yellow Coloration, the components showed a total variance of $65.28 \%$ when accounting for the variation between genotypes of the strawberry guava (Figure 1-MY). The flavonoid and ascorbic acid content was responsible in explaining the variance associated with PC1 $(35.73 \%)$, and the antioxidant activity for that of CP2 $(29.56 \%)$. Five groups were formed from the correlation matrix for the MY stage in such a way that the P1 genotype showed greater ascorbic acid than the others, and P2, P5, P12, P14 and P15 were grouped by similarity of antioxidant activity and lower flavonoid content. Ascorbic acid in fruits of P3, P8, P9, P10 and P11 was inferior to that of the other genotypes. Genotypes P4, P6 and P7 showed greater antioxidant activity, and P13 differed from the others by presenting intermediate values for antioxidant activity.

When fruits reached the Completely Yellow stage, and therefore the highest quality for consumption, the variation among genotypes was explained to $70.96 \%$ by PC1 $(42.27 \%)$ and PC2 $(28.69 \%)$ (Figure 1-CY). The variables associated with the formation of CP1 were antioxidant activity with chlorophyll and ascorbic acid content, and with the formation of $\mathrm{CP} 2$, the carotenoids. Based on the correlation matrix, four genotype groupings were possible for the CY stage. In the P4, P6 and P7 group, antioxidant activity was higher than for the other genotypes. The P1 genotype showed a greater ascorbic acid content. The $\mathrm{P} 3$ genotype showed a greater flavonoid content than did the others. Genotypes P2, P5, P8, P9, $\mathrm{P} 10, \mathrm{P} 11, \mathrm{P} 12, \mathrm{P} 13, \mathrm{P} 14$ and $\mathrm{P} 15$ showed proximity in all characteristics related to $\mathrm{CP} 1$ and $\mathrm{CP} 2$, thus characterising the maturation profile in the strawberry guava.

\section{CONCLUSIONS}

1. With the advance of fruit maturation of the strawberry guava, the ascorbic acid content increases and that of total chlorophyll and yellow flavonoids decreases;

2. The antioxidant activity of the strawberry guava increases with advancing maturity, where values are higher in the ripe fruit than those in fruit with a recognized antioxidant potential (сати-сатu, jabuticaba and uvaia). The genotypes P1, P4, P6, P7, P14 and P15 presented the greatest antioxidant activity;

3. The ascorbic acid, chlorophyll, carotenoid, and flavonoid content, and antioxidant activity account for the variability between genotypes during fruit maturation, with ascorbic acid and carotenoids being more pronounced in this variation.

\section{ACKNOWLEDGEMENT}

The authors wish to thank CNPq and CAPES for their financial support.

\section{REFERENCES}

AGOSTINI-COSTA, T. S. et al. Espécies de maior relevância para a região Centro-Oeste. In: VIEIRA, R. F. et al. Frutas Nativas da Região Centro-Oeste do Brasil. Brasília: Embrapa Recursos Genéticos e Biotecnologia, 2006. p. 12-25.

ANDRADE, J. de S.; ARAGÃO, C. G.; FERREIRA S. A. do N. Caracterização física e química dos frutos de araçá-pêra (Psidium acutangulun D. C.). Acta Amazônica, v. 23, n. 2/3, p. 213-217, 1993.

ARORA, A.; NAIR, M. G.; STRASBURG, G. M. Structureactivity relationships for antioxidant activities of a series of flavonoids in a liposomal system. Free Radical Biology \& Medicine, v. 24, n. 9, p. 1355-1363, 1998.

ASSOCIATION OF OFFICIAL ANALYTICAL CHEMISTS INTERNATIONAL. Official Methods of analisys of AOAC International. 18. ed. Maryland, USA., 2006.

AZZOLINI, M.; JACOMINO, A. P.; BRON, I. U. Índices para avaliar qualidade pós-colheita de goiabas em diferentes estádios de maturação. Pesquisa Agropecuária Brasileira, v. 39, n. 2, p. 139-145, 2004.

BADEJO, A. A.; FUJIKAWA, Y.; ESAKA, M. Gene expression of ascorbic acid biosynthesis related enzymes of the SmirnoffWheeler pathway in acerola (Malpighia glabra) Journal of Plant Physiology, v. 166, n. 6, p. 652-660, 2009.

BEZERRA, J. E. F. et al. Araçá. In: VIEIRA, R. F. et al. Frutas Nativas da Região Centro-Oste do Brasil. Brasília: Embrapa Recursos Genéticos e Biotecnologia, 2006. p. 42-63. 
BRITO PRIMO, D. M. Aspectos da fisiologia da maturação e da conservação pós-colheita de araçá (P. cattleyanum). 2005, 43 f. Monografia (Graduação em Agronomia) Universidade Federal do Paraíba, Areia, 2005.

BRUUINSMA, J. The quantitative analysis of clorophylls A and $B$ in plant extracts. Photochemistry and Photobiology, v. 2, n, 2, p. 241-249, 1963.

Chitarra, M. I.; Chitarra, A. B. Pós-colheita de Frutos e Hortaliças: Fisiologia e manuseio. 2. ed. Lavras: UFLA, 2005. 785 p.

BREZEANU, C.; BREZEANU, P. M.; AMBARUS, S. Studies Regarding Physiological and Biochemical Changes during the Ripening Process in Cucumis melo. Journal of Horticulture Forestry and Biotechnology, v. 14, n. 1, p. 266-269, 2010.

DEGÁSPARI, C.H.; WASZCZYNSKYJ, N. Antioxidants properties of phenolic compounds. Visão Acadêmica, v. 5, p. 33-40, 2004.

FETTER, M. da R. et al. Propriedades funcionais de araçáamarelo, araçá-vermelho (Psidium cattleyanum Sabine) e araçápêra ( $P$. acutangulum D.C) cultivados em Pelotas/RS. Brazilian Journal of Food Technology, n. 15, p. 92-95, 2010.

FRANCIS, F. J. Analysis of anthocyanins. In: MARKAKIS, P. (Ed.). Anthocyanins as food colors. New York: Academic Press, 1982. p. 181-207.

GENOVESE, M. I. et al. Bioactive compounds and antioxidant capacity of exotic fruits and commercial frozen pulps from Brazil. Food Science and Technology International, v. 14, n. 3, p. 207-214, 2008.

GIACOBBO, C. L. et al. Avaliação do teor de vitamina c em diferentes grupos de araçá-comum. Revista Brasileira de Agrociência, v. 14, n. 1, p. 155-159, 2008.

GONÇALVES, A. E. S. S.; LAJOLO, F. M.; GENOVESE, M. I. Chemical Composition and Antioxidant/Antidiabetic Potential of Brazilian Native Fruits and Commercial Frozen Pulps. Journal of Agricultural Food Chemistry, v. 58, n. 8, p. 4666-4674, 2010.
KUSKOSKI, E. M. et al. Frutos tropicais silvestres e polpas de frutas congeladas: atividade antioxidante, polifenóis e antocianinas. Ciência Rural, v. 36, n. 4, p. 1283-1287, 2006.

MUSA, K. H. et al. Antioxidant activity of pink-flesh guava (Psidium guajava L.): effect of extraction techniques and solvents. Food Analytical Methods, v. 4, p. 100-107, 2011.

PALIYATH, G.; MURR, D. P. Biochemistry of Fruits. In: PAliYATH, G. et al. (Ed.). Postharvest Biology and Technology of Fruits, Vegetables and Flower. WileyBlackwell Publishing, 2008. p. 19-50.

PATIL, A. G. et al. Physical and chemical characteristics of carambola (Averrhoa carambola L.) fruit at three stages of maturity. International Journal of Applied Biology and Pharmaceutical Technology, v. 1, n. 2, p. 624-629, 2010.

ROJAS-BARQUERA, D.; NARVÁEZ-CUENCA, C. E. Determinación de vitamina c, compuestos fenólicos totales y actividad antioxidante de frutas de guayaba (Psidium guajava L.) cultivadas en Colômbia. Química Nova, v. 32, n. 9, p. 2336-2340, 2009.

RUFINO, M. do S. M. et al. Bioactive compounds and antioxidant capacities of 18 non-traditional tropical fruits from Brazil. Food Chemistry, v. 121, n. 4, p. 996-1002, 2010 .

SILVA, M. M. et al. Structure-antioxidant activity relationships of flavonoids: a re-examination. Free Radical Research, v. 36, n. 11, p. 1219-1227, 2002.

SOUZA, M. E. de. et al. Influência das precipitações pluviométricas em atributos físico-químicos de frutos da goiabeira 'Paluma' em diferentes estádios de maturação. Revista Brasileira de Fruticultura, v. 32, n. 2, p. 637-646, 2010.

STATSOFT, Inc. STATISTICA: (data analysis software system), version 7. 2004. Disponível em: <www.statsoft. com>. Acesso em: 10 fev. 2012. 